\title{
Interest Rates, Fuel Subsidies, and Investment Friendliness in Southeast Asia
}

\author{
Siangling $\mathrm{Lu}$ \\ School of Economic, Political and Policy Sciences, The University of Texas at Dallas, Richardson, Texas, USA, \\ sx150330@utdallas.edu
}

\begin{abstract}
The question of investment determinants has been widely debated in the economic field, with scholars such as Daude and Stein (2007) and Waheed (2015) citing institutional quality as key while Ibrahim (2011), Jongwanich and Kohpaiboon (2008) cite financial market conditions as key. However, the role of fuel subsidies in affecting investment friendliness in smaller-scale oil producing countries have not been sufficiently addressed. My paper investigates determinants of investment friendliness in Southeast Asia with special attention to fuel subsidies. Specifically, in my project, I examined the interactions between lending interest rates, fuel subsidies, and gross fixed capital formation to carry out qualitative case studies on oil producing countries. I theorize that countries with higher fuel subsidies are likely to be less investment friendly than countries with lower fuel subsidies. This project, by closely examining fuel subsidies, sheds new light on the rarely acknowledged issue of fuel subsidies and investment friendliness.
\end{abstract}

KEYWORDS: Fuel Subsidies, Gross Fixed Capital Formation, Interest Rates, Investment Friendliness, Southeast Asia

\section{Introduction}

Indonesia and Malaysia are neighboring Southeast Asian countries, sharing cultural roots and a similar colonial history by the Dutch and the British respectively. Located between the Indian Ocean and the South China Sea, the countries lie along prominent trade routes that connected East Asia to the rest of the world. This provides both countries with similar access to trade and similar opportunities for economic liberalization. Due to the close proximity between the two countries, both countries are also similar in resource endowments. The U.S. Energy Information Administration (2016) found that proved crude oil reserves in Indonesia is at 3.7 billion barrels while Malaysia currently has about 3.6 billion barrels. Additionally, Sovacool (2010), found that both Indonesia and Malaysia, along with a handful of oil-producing Southeast Asian countries, have managed to circumvent the resource curse, indicating that the natural resource endowments of both countries have not been detrimental to the growth of both countries.

With its similar location, history, and resource endowments, the preconditions for economic development in both countries provide a set of comparable circumstances that forecast parallel development trajectories. However, the past few decades saw a huge discrepancy in the economic development of both countries. The World Bank (2018) ranks Malaysia at $24^{\text {th }}$ in the world for ease of doing business while Indonesia ranks at 72. Data from the UN Conference on Trade and Development (2017) further indicates that inwards FDI stock in Malaysia accounts for $41 \%$ of GDP and only $25.2 \%$ in Indonesia in 2016. Malaysia is significantly more investment friendly than Indonesia, ranking higher than Indonesia in terms of registering property, getting credit, and paying taxes among other topics. Malaysia's investment friendly economy and the resulting disparity between the economic progress of both countries can also be seen in the differences in GDP per capita between the two countries. The IMF (2017) indicates that the GDP per capita in Malaysia is 10490 USD while Indonesia's is less than half of that, at 4120 USD. Why is Malaysia able to develop a more investment friendly economy when Indonesia, endowed with similar oil reserves, geographic location, and colonial history, lags significantly behind Malaysia in terms of investment friendliness?

\section{Existing Literature}

One explanation for the differences in business environment lies in differences in the quality of institutions. Good institutions foster more dynamic business environment and heighten investor confidence, encouraging both domestic and foreign investments through an efficient regulatory 
environment, protection of property rights and the overall governance efficacy. These qualities minimize political and regulatory risks for investors, thus cultivating a more welcoming environment for investments. In comparing the quality of institution, countries with better institutions are more likely to be more investment friendly than those with bad institutions. For example, Daude and Stein (2007) found that deterrents to foreign direct investments include excessive regulations, unpredictable policies, and insufficient property rights protection. Similarly, Waheed (2015) stated that advancements in rule of law encourages domestic private investment both in the short run and long run. Furthermore, Morrissey and Udomkerdmongkol (2011) found that good governance and political stability increases private and foreign investments across a sample of developing countries. Differences in institutional quality is therefore a possible explanation for the divergences in business environment in the research puzzle.

Domestic financial market conditions are also likely determinants of investment friendliness. Potential investors with easier access to credit are more likely to invest while stable market conditions reduce uncertainty. As a result, countries with more robust financial market conditions will likely be more investment friendly than those with less developed financial market conditions. Jongwanich and Kohpaiboon (2008) found that shortages in credit availability deterred the recovery of Thailand's private investment sector after the great recession of 2007-2009. Additionally, Ibrahim (2011) found that rising real stock prices correlate with increasing aggregate investments, while stock price volatility correlates with decreasing aggregate investments. Ndikumana's (2000) research took on a broader perspective on the effects of financial market conditions, finding that higher development in the financial sector leads to higher domestic investments by analyzing a variety of financial indicators for financial development across sub-Saharan Africa. Financial market conditions, therefore, are a possible explanation towards differences in investment friendliness.

\section{Theory}

The investment friendliness of a country can also be determined by the magnitude of governmentsponsored fuel subsidies. High government fuel subsidies take away from spending on national public goods, deterring growth and development. I hypothesize that higher government fuel subsidies will likely correlate with lower investment friendliness. Government spending to provide social welfare or stimulate economic growth are diverted to subsidies, inhibiting economic growth of a country. Mundaca's (2017) research is the closest to this hypothesis, linking reduced subsidies to long-run growth, but there was no mechanism that link fuel subsidies to investment friendliness. Plante's (2016) research attribute the loss of social welfare to fuel subsidies, with market distortions, instead of the source of funding, being the root cause of welfare losses. Expanding upon their research, I theorize that the fossil fuel subsidies create economic inefficiencies, such as price distortions and market inefficiencies to prevent the economy from operating at its full capacity, hereby inhibiting long-run growth and diminishing investment opportunities for investors.

High fuel subsidies can also lead to lower investment friendliness through an alternative causal mechanism. Cheon, Lackner, and Urpelainen (2013) linked high fuel subsidies with weak institutions with limited institutional instruments. Political instability that are linked to weak institutions can therefore be a key deterrent to investments, resulting in low investment friendliness due to political risks associated with investments, such as regulatory and expropriation risks. These two devices address both economic and political mechanisms in which higher fuel subsidies lead to lower economic growth. Therefore, I theorize that in comparing government fuel subsidies, countries with less government fuel subsidies are likely to be more investment friendly that those with more government fuel subsidies.

\section{Research Design}

To test the hypotheses on the determinants of investment friendliness, I will be using a qualitative case study as it allows for objective examination of evidence on a case-by-case basis. Existing hypothesis addressing the determinants of investment include institutional quality and financial market conditions. The better the institutional quality, the more investment friendly a country is; while better 
financial market conditions will lead to higher investment friendliness. I find the second hypothesis more convincing as institutional quality is a more subjective measure, often beholden to assumptions and personal biases, with widespread disagreement on the exact definitions and methods of determining institutional quality. Contrastingly, financial market conditions are more quantitative, and are easier to be represented by objective data. Forgoing the institutional quality hypothesis, I will be testing these hypotheses. Firstly, in comparing financial market conditions, countries with better financial market conditions are more likely to be more investment friendly than countries with worse financial market conditions. Secondly, in comparing fuel subsidies, countries with higher levels of fuel subsidies are more likely to be less investment friendly than countries with lower levels of fuel subsidies. I will be examining data from 2009 -2011. The time frame allows for minimizing the risk of distorted results from variables such as political instability in past decades. Additionally, utilizing data from the time period allowed for the data to be suitably adjusted.

The independent variables are financial market conditions and fuel subsidies. To examine financial market conditions, I will be using lending interest rates as the indicator. This is appropriate as the lending interest rate can be perceived as the cost of borrowing. High cost of borrowing can deter potential investors, thereby decreasing aggregate investments in the domestic market, lowering investment friendliness. The lending interest rate can therefore insinuate market demand for loans, while also indicating credit accessibility. To oversimplify, a lower lending interest rate indicates better financial market conditions, where credit is more readily available due to lower costs of borrowing, resulting in higher demand for loans that can be utilized for investments. Bad financial market conditions correlate with higher lending interest rates, where the cost of borrowing is higher, demand for credit and credit availability are lower. Data on the lending interest rate will be sourced from the World Bank. Fuel subsidies will be measured as the total amount of government energy subsidy as a percentage of public expenditure, sourced from the International Institute of Sustainable Development. This is appropriate as the hypothesis addresses the adverse impact of fuel subsidies through the diversion of public spending from social welfare. By measuring subsidies in terms of public spending, the magnitude of diverted funds can therefore by captured.

A set of 4 similar countries with varying degrees of lending interest rates and fuel subsidies are listed in the Table 1 along with their mean lending interest rates and fuel subsidies as a percentage of public expenditure from 2009-2011. These countries are selected due to their geographic proximity as they are all countries in Southeast Asia, sharing access to strategic waterways and have all experienced significant economic growth in recent decades. Within these countries, Thailand and Malaysia have lower lending interest rates, indicating better financial market conditions while Indonesia and Vietnam have higher lending interest rates, indicating worse financial market conditions. Conversely, Thailand and Indonesia's fuel subsidies as a percentage of public expenditure are higher than Malaysia's and Vietnam's.

Table 1. Theory and Data (Fuel Subsidies, Lending Interest Rates)

\begin{tabular}{|l|l|l|}
\hline & Good Financial Market Conditions & Bad Financial Market Conditions \\
\hline High Fuel Subsidies & Thailand $(11.13 \%, 4.73 \%)$ & Indonesia $(13.43 \%, 13.38 \%)$ \\
\hline Low Fuel Subsidies & Malaysia $(8.34 \%, 5 \%)$ & Vietnam $(8.87 \%, 13.37 \%)$ \\
\hline
\end{tabular}

To measure the dependent variable, investment friendliness, I will be utilizing the World Bank Data on gross fixed capital formation as a percentage of GDP as it measures the addition of capital stock in a given timeframe. A higher percentage indicative of a more investment friendly economy as a greater number of new capital formation signifies an environment that is more conducive for investments. Inversely, a lower percentage of gross fixed capital formation as a percentage of GDP is indicative of a less investment friendly economy. I will first examine the correlation between independent variables and the dependent variables in the four countries above and analyze the robustness of each hypothesis. Then, in comparative case studies, I will trace the qualitative causal mechanisms to explain the correlation between the winning hypothesis and the dependent variable. 


\section{Findings}

The first hypothesis theorizes that countries with better financial market conditions are more likely to be investment friendly. Under that hypothesis, Thailand and Malaysia, with their lower lending interest rates, are expected to have high rankings in investment friendliness while Indonesia and Vietnam are expected to have low rankings in investment friendliness. The second hypothesis speculates that countries with higher government fuel subsidies are likely to be less investment friendly. The second hypothesis therefore denotes that Vietnam and Indonesia are expected to have low rankings in investment friendliness while Malaysia and Thailand are expected to have high rankings in investment friendliness.

Applying World Bank data on gross fixed capital formation as the indicator for the dependent variable, Indonesia and Vietnam experiences a higher percentage of capital formation when compared to Malaysia and Thailand. This is represented in table 1.2.

Table 1.2. Hypothesis and gross fixed capital formation

\begin{tabular}{|l|l|l|}
\hline & Good Financial Market Conditions & Bad Financial Market Conditions \\
\hline High Fuel Subsidies & Thailand (24.31\%) & Indonesia (31.14\%) \\
\hline Low Fuel Subsidies & Malaysia (22.2\%) & Vietnam (31.11\%) \\
\hline
\end{tabular}

Based on these findings, the second hypothesis on fuel subsidies fails to stand. Indonesia and Thailand, with higher fuel subsidies, are expected to have lower gross fixed capital formation but Indonesia's capital formation is significantly higher than even the low-subsidy country of Malaysia. There is therefore no significant relationship between fuel subsidies and investment friendliness, rendering the second hypothesis obsolete. When examining financial market conditions and investment friendliness, the results are the opposite from what is expected. I theorized that low lending interest rates will correlate with a high percentage of gross fixed capital formation while high lending interest rates will correlate with low percentage of gross fixed capital formation. However, the figures indicate that countries with higher lending interest rates have a higher percentage of fixed capital formation. The existence of this pattern indicate that a relationship exists between the variables, albeit not the hypothesized correlation. I will thus be investigating the causal mechanisms as to how better financial market conditions lead to lower gross fixed capital formation in Malaysia and Vietnam as they show the greatest discrepancy between their mean gross fixed capital formation from 2009 to 2011.

The mechanism by which interest rates affect investment is straightforward. Higher lending interest rates result in higher cost of borrowing, which discourages investment lending, thus resulting in lower investment friendliness. As the opposite pattern is evident in the data, the context in which these variables operate is worthy of further scrutiny. Vietnam went through a series of economic malaise in the 70s and 80s as five-year plans and a centrally planned economy brought upon crises and hyperinflation. Following Vietnam's transition from a command to market economy in 1986, Vietnam's economy underwent rapid expansion due to the influx of Foreign Direct Investments (FDI) while subsequent decades of increasing economic liberalization encouraged further growth regardless of setbacks from the 1997 Asian financial crisis. Investment growth was high as gross fixed capital formation from 2000-2008 averages at about 31.5\% at the cost of high inflation. Nguyen and Nguyen's (2010) analysis attributes consistent high inflation with delayed monetary policy actions. Sudden influxes of foreign currency in 2006 resulted in mismanagement of foreign exchange policy, resulting in high interest rates in response to high inflation.

Malaysia, in contrast, enjoyed relative macroeconomic stability. Rapid economic growth in prior decades were aided by high influxes of FDI in the 90s and a variety of government incentives that in the attraction of investments. Sound monetary policy decisions allow the government to utilize low interest rates as a method to control investment spending through capital costs and firm-level cash flow, as detailed by Karim and Azman-Saini (2013). While lending interest rates continue in a downwards trend following the fall of FDI levels after the Asian financial crisis, gross fixed capital formation remained constant, averaging at $22.72 \%$ from 2000-2008. Although lower than Vietnam's 
average in the same time period, Malaysia's economy remained less volatile. The trend of low lending interest rates in Malaysia is therefore indicative of long-term macroeconomic stability stemming from preceding decades of export-led growth.

The reversal of expectations in the interactions between interest rates and capital formation can be attributed to varying policy decisions made in the fallout of the 2008 recession. 2008 saw a gradual slowdown of Vietnam's economic growth, particularly in the manufacturing sector. In order to maintain production levels, an economic stimulus package that include an interest rate subsidy of $4 \%$ for 8 months was enacted by the government in early 2009 amidst outcries from analysts and policy makers. Nevertheless, public reaction to the subsidies were favorable. An article on Vietnam News (2009) detailed the domestic demand to expand such subsidies to grassroot credit funds as subsidies were lowered to approximately 6\%. Dinh, Malesky, To, and Nguyen (2012) correlated increased labor utilization and investment expansion to the interest rate subsidies. As a result, gross fixed capital formation rate remained constant when compared to post-2009 figures. The interest rate subsidies, despite the hefty cost of 1 billion USD from 2009 public expenditure, succeeded initially in maintaining regular investment levels even amidst declining global consumption, interest rate subsidies, coupled with a trend of high gross fixed capital formation, is therefore a possible explanation on how Vietnam's capital formation is higher despite its higher lending interest rate.

Similarly, the 2008 recession marks the declining of global demand for Malaysian exports. Monetary policy measures in 2009, notably allowing the currency depreciation through capital outflows and the lowering of interest rates, allowed the government to minimize the impact of the financial crisis on the economy (Elekdag, et al. 2012). As a result, inflation in 2009 was $0.583 \%$, with GDP growth at $-1.51 \%$ in 2009 signifying deflation and a contraction of the economy. Contrastingly, Vietnam's GDP growth was 5.39\% in 2009. Despite economic contraction, the adverse effects of Malaysian monetary policies pale in comparison to Vietnam's. Ruwitch and Tran (2011) report that small businesses were struggling to survive as inflation soared to a high of $18.7 \%$ in Vietnam. Lending interest rates, in comparison, are at $16.95 \%$ while gross fixed capital formation declined to $26.8 \%$ of GDP from $33.86 \%$ in 2009 . Gross fixed capital formation remained constant in Malaysia at $22.43 \%$ and $22.183 \%$ in 2010 and 2011. GDP growth resumed in 2010 at $7.267 \%$. It is therefore possible that ineffective public spending, coupled with mismanagement of state-owned enterprises in Vietnam are to blame for later economic shortcomings. In short, the discrepancy between the hypothesis and the actual findings is due to Vietnam's interest rate subsidies in 2009 that forcibly lowered the cost of acquiring capital, while Malaysia, with lower interest rate, and less radical policies, continued with slower but stable growth throughout the recession. Interest rate subsidy is therefore an extraneous variable that offsets the macroeconomic interactions between investment rates and lending interest rates.

\section{Conclusion}

In conclusion, the fuel subsidy hypothesis fails to stand as there is no significant indication that higher fuel subsidies result in lower investment friendliness. However, in examining financial market conditions, lower lending interest rates, and therefore more favorable financial market conditions correlate with lower levels of investment friendliness, defying initial expectations for the first hypothesis.

Research on resource endowments in the Southeast Asia region is often overlooked in favor of their more oil-rich counterparts. While fuel reserves and production in Southeast Asia pales in comparison to other more prominently oil-reliant regions in the world, such as the Middle East and Latin America, case studies of these countries can nonetheless provide insight into the role of exogenous factors in natural resources and economic development. These countries also provide a unique set of similar conditions that allow for the establishing of strong control variables that are uncommon in social science research. Furthermore, the circumventing of a direct resource curse by these countries enables the exploration of alternative approaches regarding the impact of natural resource endowments to economic development. While the resource curse and the Dutch Disease are often the subject of academic scrutiny, the investigation of these case studies, unimpeded by the 
resource curse, diversifies the field of similar research by focusing on countries without the natural resource curse.

Major shortfalls of this research come in the form of insufficient primary sources of information as recent and accurate data on energy subsidies are difficult to come by. By using only lending interest rates as the indicator of good financial market conditions, overall health and development of country-specific financial markets are insufficiently accounted for.

\section{References}

Alp, H., Elekdag, S., and Lall, S. 2012. “An Assessment of Malaysian Monetary Policy During the Global Financial Crisis of 2008-2009”. International Monetary Fund Working Papers.

Azman-Saini, W, and Karim, Z. 2013. "Firm-level Investment and Monetary Policy in Malaysia: do the Interest Rate and Broad Credit Channels Matter?" Journal of Asia Pacific Economy 18(3):396-412.

Cheon, A., Lackner, M., and Urpelainen, J. 2013. "Why do Governments Subsidize Gasoline Consumption? An Empirical Analysis of Global Gasoline Prices, 2002 - 2009." Energy Policy 56:382-390.

Daude, C., \& Stein, E. 2007. “The Quality of Institutions and Foreign Direct Investment.” Economics \& Politics 19(3):317-344.

Dinh, T., Malesky, E., Nguyen, D., and To, T. 2012. "Effects of Interest Rate Subsidies on Firm Performance and Investment Behavior during Economic Recession: Evidence from Vietnam.” Asian Economic Journal 2013 27(2):185-207

Hong Thuy, "Credit Union Calls for Interest Rate Subsidy.” Vietnam News, February 27, 2009. https://vietnamnews.vn/e conomy/185633/credit-union-calls-for-interest-rate-subsidy.html\#xtzMz0aqw3mJTC2y.97

Ibrahim, M. 2011. "Level and Volatility of Stock Prices and Aggregate Investment: The Case of Thailand." Global Economic Review 40(4):445-461.

International Institute of Sustainable Development. “Total Energy Subsidies.” Global Subsidies Initiative. Accessed July $15^{\text {th }}, 2018$. http://www.iisd.org/gsi/interactive-data/total-0.

International Monetary Fund (IMF). 2017. “GDP per capita.” IMF Data Mapper. Accessed February $17^{\text {th }} 2018$, http://www.imf .org/external/datamapper.

John Ruwitch and Tran le Thuy, “Inflation, High Rates Batter Vietnam’s Small Businesses.” Reuters, June 27, 2011, https://www.reuters.com/article/us-vietnam-economy-idUSTRE75R0ID20110628.

Jongwanich, J., \& Kohpaiboon, A. 2008. "Private Investment: Trends and Determinants in Thailand." World Development 36(10):1709-1724.

Morrissey, O., \& Udomkerdmongkol, M. 2011. “Governance, Private Investment and Foreign Direct Investment in Developing Countries.” World Development 40(3):437-445.

Mundaca, G. 2017. “Energy Subsidies, Public Investment, and Endogenous Growth.” Energy Policy 110:693-709.

Ndikumana, L. 2000. "Financial Determinants of Domestic Investment in Sub-Saharan Africa: Evidence from Panel Data." World Development 28(2):381-400.

Nguyen, H., and Nguyen, T. “Macroeconomic Determinants of Vietnam's Inflation 2000-2010: Evidence and Analysis.” United Nations Development Programme Vietnam.

Plante, M. 2013. “The Long Run Macroeconomic Impacts of Fuel Subsidies.” Federal Reserve Bank of Dallas. Working Paper 1303.

Quan, V. 2014. "Vietnam's Political Economy in Transition.” Stratfor Worldview.

Sovacool, B. 2010. "The Political Economy of Oil and Gas in Southeast Asia: Heading towards the Natural Resource Curse?" The Pacific Review 23(2), 225-259.

United Nations Conference on Trade and Development. 2017. "World Investment Report Factsheet: Investment in the Digital Economy." UNCTAD. Accessed January 25 th 2018 . http://unctad.org/en/PublicationsLibrary/wir2017en.

United States Energy Information Association. 2017. "Crude Oil Proved Reserves. " International Energy Statistics. Accessed January $17^{\text {th }}, 2018$. https://www.eia.gov/beta/international/data/browser.

Waheed, A. 2015. "Determinants of Domestic Private Investment: Test of Alternative Hypotheses for Pakistan." International Journal of Research in Business and Social Science 4(2), 35-43.

World Bank. 2018. "Ease of Doing Business Index." World Bank. Accessed January 25 ${ }^{\text {th }}, 2018$. http://www.doingbusines s.org/rankings.

World Bank. 2018. “Lending Interest Rate.” World Bank Data. Accessed March 27 ${ }^{\text {th }}$, 2018. https://data.worldbank.org/ind icator/FR.INR.LEND?end=2012\&locations=MY-ID-VN-TH\&start=2000\&view $=$ chart

World Bank. 2018. "Fixed Capital Formation." World Bank Data. Accessed June 28 $8^{\text {th }}, 2018$. https://data.worldbank.org/i ndicator/NE.GDI.TOTL.ZS?end=2012\&locations=ID-MY-TH-VN\&start=2000 